\title{
PENGELOLAAN PUPUK KANDANG SAPI DALAM RANGKA MENINGKATKAN MUTU DI DESA JETIS, KECAMATAN SAMBIREJO, KABUPATEN SRAGEN
}

\author{
Slamet Minardi, Suryono \\ Program Studi Ilmu Tanah Fakultas Pertanian, Universitas Sebelas Maret Surakarta \\ Email: sminardi@staff.uns.ac.id
}

\begin{abstract}
ABSTRAK
Program PKM ini bekerjasama dengan dua mitra, yaitu: (1) Kelompok Ternak "Lembu Mulyo", dan (2) Kelompok Ternak "Andini”. Mitra (1) dan Mitra (2) berlokasi di Desa Jetis, Kecamatan Sambirejo, Kabupaten Sragen, dengan jarak tempuh sekitar $39 \mathrm{~km}$ dari Fak. Pertanian UNS. Bidang usaha yang dikembangkan oleh kedua mitra tersebut adalah usaha peternakan sapi. Lokasi kedua mitra sangat berdekatan, hanya sekitar $1,2 \mathrm{~km}$. Permasalahan dihadapi yaitu banyaknya kotoran sapi yang kurang bermutu dan kurang termanfaatkan, produksi limbah ternak sapi (kotoran sapi) yang sangat tinggi, yaitu sekitar $100 \mathrm{~kg}$ limbah per hari (3 ton per bulan) pada masing-masing mitra, dan jika hal ini dibiarkan akan menjadi tumpukan kotoran sapi yang sangat berbau yang mengganggu lingkungan. Kegiatan yang dilakukan meliputi: koordinasi dengan mitra dan pendampingan pengelolaan/pengolahan kotoran sapi melalui fermentasi yang diperkaya dengan bakteri perombak, yang dapat menambah ketersediaan $\mathrm{N}, \mathrm{K}$ dan $\mathrm{Ca}$ sebagai pupuk organik yang sangat bermutu
\end{abstract}

Kata kunci: pupuk kandang sapi, pertanian organic, kelompok tani

\section{PENDAHULUAN}

Program PKM ini bekerjasama dengan dua mitra, yaitu: (1) Kelompok Ternak "Lembu Mulyo", dan (2) Kelompok Ternak "Andini". Kedua Mitra berlokasi di Desa Jetis, Kecamatan Sambirejo, Kabupaten Sragen, dengan jarak tempuh sekitar $39 \mathrm{~km}$ dari Fak. Pertanian UNS. Bidang usaha yang dikembangkan oleh kedua mitra tersebut adalah usaha peternakan sapi. Lokasi kedua mitra sangat berdekatan, hanya sekitar $1 \mathrm{~km}$. Permintaan terhadap pupuk organik dalam menuju pertanian organik sangat tinggi, belum mampu dipenuhi oleh kedua mitra usaha tersebut yang perlu ditingkatkan terus, baik kualitas maupun kuantitas.

Kelompok Tani "Lembu Mulyo" merupakan suatu kelompok tani yang bergerak dalam usaha peternakan sapi. Kelompok tani ini terdiri dari 15 anggota, yang masing-masing anggota rata-rata memiliki 2 sampai 3 ekor sapi. Manajemen yang dikembangkan dalam kelompok tani ini berdasarkan kegotongroyongan/ kebersamaan.

Sedangkan Kelompok Tani "Andini" juga merupakan suatu kelompok tani yang bergerak dalam usaha peternakan sapi. Kelompok tani ini terdiri dari 15 anggota, yang masing-masing anggota rata-rata memiliki 2 sampai 3 ekor sapi. Manajemen yang dikembangkan dalam kelompok tani ini juga berdasarkan kegotongroyongan/ kebersamaan.

Permasalahan yang dihadapi Mitra 1 ("Lembu Mulyo") dan Mitra 2 (“Andini”) adalah banyaknya kotoran sapi yang belum termanfaatkan, produksi limbah ternak sapi (kotoran sapi) yang sangat tinggi, yaitu sekitar $100 \mathrm{~kg}$ limbah per hari (3 ton per 
bulan) pada masing-masing mitra, dan jika hal ini dibiarkan akan menjadi tumpukan kotoran sapi yang sangat berbau yang mengganggu lingkungan, apabila dikelola/diolah/ difermentasi diperkaya dengan bakteri perombak bisa digunakan sebagai pupuk organik yang sangat bermutu. Dalam usaha peternakan sapi ini ingin mengarah pada peternakan yang ramah lingkungan sehingga tidak menjadi masalah di masyarakat. Apabila dikelola dengan baik akan dapat digunakan sebagai pupuk organik yang sangat bermanfaat dan dapat meningkatkan kesuburan tanah secara terus menerus dan apabila diberikan terus menerus akan menuju pertanian organik berkelanjutan.

Pupuk organik diantaranya ditandai dengan ciri-ciri Nitrogen terdapat dalam bentuk persenyawaan organik sehingga mudah dihisap tanama; Tidak meninggalkan sisa asam anorganik didalam tanah. Mempunyai kadar persenyawaan $\mathrm{C}$ organik yang tinggi, misalnya hidrat arang (Murbandono, 2000).

Memelihara sapi sangat menguntungkan, karena tidak hanya menghasilkan daging atau susu tetapi juga menghasilkan pupuk kandang. Kotoran sapi memiliki nilai ekonomis karena termasuk pupuk organik yang dibutuhkan oleh semua jenis tumbuh- tumbuhan. Sebagian besar kotoran hewan dapat digunakan untuk pupuk setelah mengalami pengomposan yang matang, yaitu bila secara fisik (warna, rupa, tekstur dan kadar air) tidak serupa dengan bahan aslinya, secara kimia memiliki kandungan bahan organik: $60-70 \%, \mathrm{~N}: 2 \%$, P2O5: $1 \%, \mathrm{~K} 2 \mathrm{O}: 1 \%$. Jenis kotoran hewan yang umum digunakan adalah kotoran sapi, kerbau, kelinci, ayam, dan kambing.

Secara umum kotoran sapi banyak digunakan sebagai pupuk kandang karena ketersediaannya lebih banyak dibandingkan kotoran hewan lain. (Setiawan, 1998). Pupuk kandang selain mengandung unsur-unsur zat hara serta mineral juga bisa memperbaiki struktur tanah seperti halnya pupuk kompos (Rahardi et al., 1995). Kelebihan pupuk kandang adalah dapat meningkatkan humus, memperbaiki struktur tanah, dan meningkatkan kehidupan mikroorganisme pengurai (Zulkarnain, 2009). Cara kerja dari pupuk kandang ini cara kerjanya yang lamban. Oleh karena itu ia amat cocok digunakan sebagai pupuk dasar (Hidayat dan Darwin, 2008).

Kompos yang dihasilkan dengan fermentasi menggunakan teknologi mikrobia efektif dikenal dengan nama bokashi. Dengan cara ini proses pembuatan kompos dapat berlangsung lebih singkat dibandingkan cara konvensional (Yuwono, 2007).

Kegiatan PKM ini berusaha untuk mengatasi permasalahan yang dihadapi mitra usaha dengan memanfaatkan pupuk kandang dari mitra (1) dan mitra (2) untuk dimanfaatkan sebagai pupuk organik. Penerapan teknologi yang diusulkan akan menghasilkan kegiatan peternakan sapi yang ramah lingkungan dan saling menguntungkan.

\section{METODE PENGABDIAN}

Solusi yang ditawarkan untuk mengatasi permasalahan yang dihadapi mitra adalah membuat pupuk organik dengan memanfaatkan kotoran sapi yang dikomposkan dengan menggunakan starbio/bakteri dekomposer yang dapat membuat unsur-unsur hara lebih tersedia bagi tanaman dan dapat digunakan sebagai pupuk organik yang sangat bermanfaat dan dapat meningkatkan kesuburan tanah secara terus menerus dan apabila diberikan terus menerus akan 


\section{HASIL KEGIATAN}

Kegiatan pengabdian ini diawali dengah survey awal untuk mengetahui tingkat pengetahuan mitra, kondisi lingkungan dan proses perijinan. Koordinasi dengan mitra untuk menentukan waktu, tempat pelaksanaan serta materi yang dibutuhkan mitra. Selanjutnya dilakukan penyiapan peralatan dan perlengkapan pelatihan. serta penyusunan modul/materi pelatihan yang dilanjutkan dengan praktek pembuatan pupuk organic.

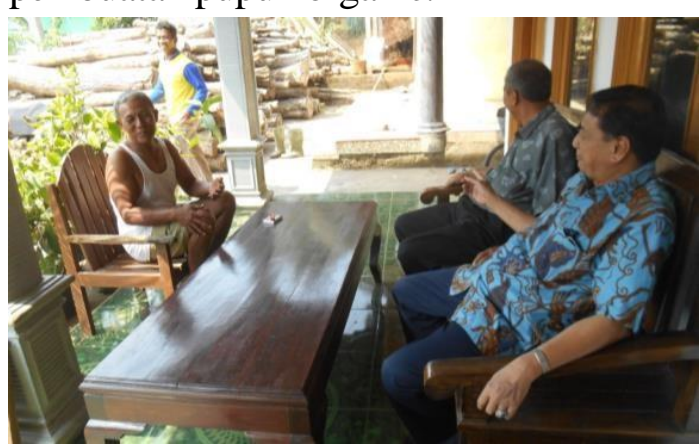

Gambar 1. Koordinasi dengan Mitra merencanakan pelaksanaan kegiatan.

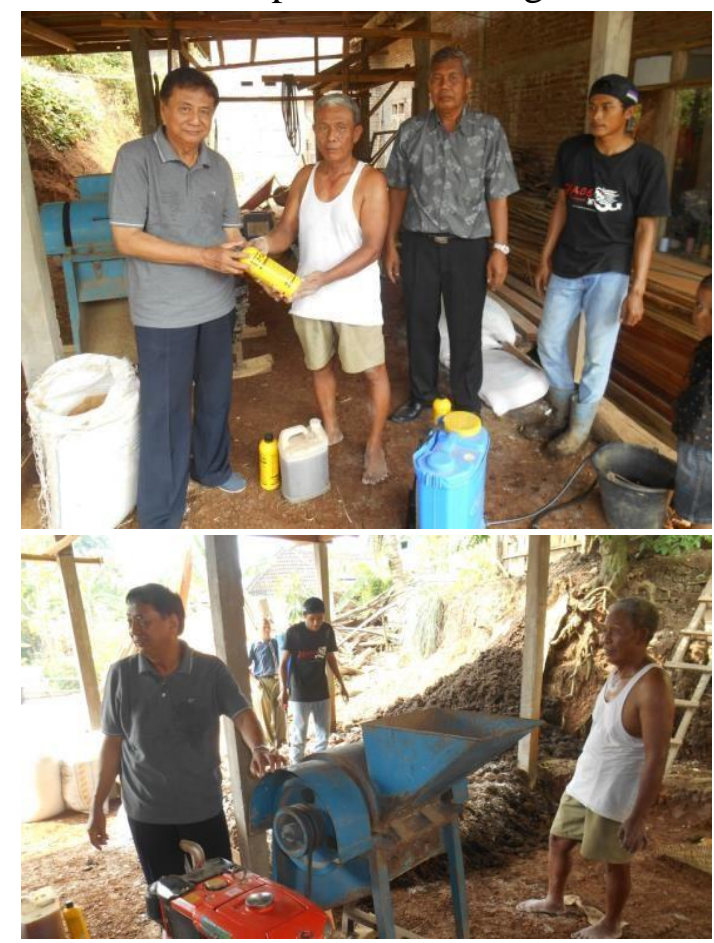

Gambar 2. Persiapan bahan-bahan pengolahan pupuk kandang

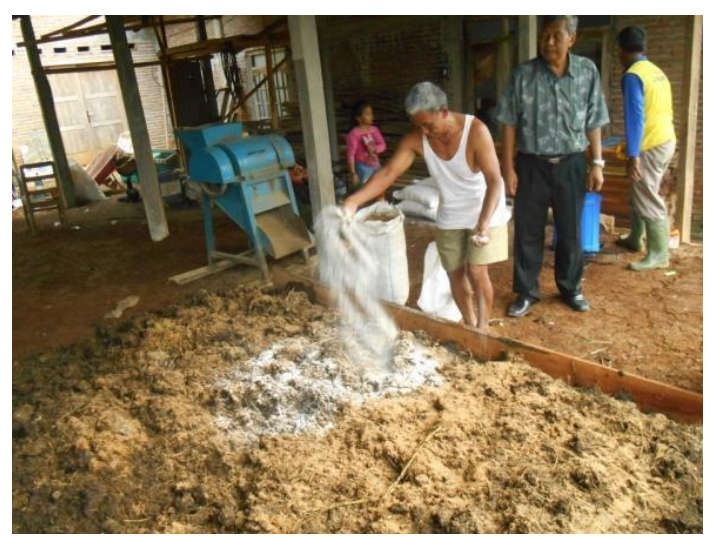

Gambar 3. Penambahan Dolomit

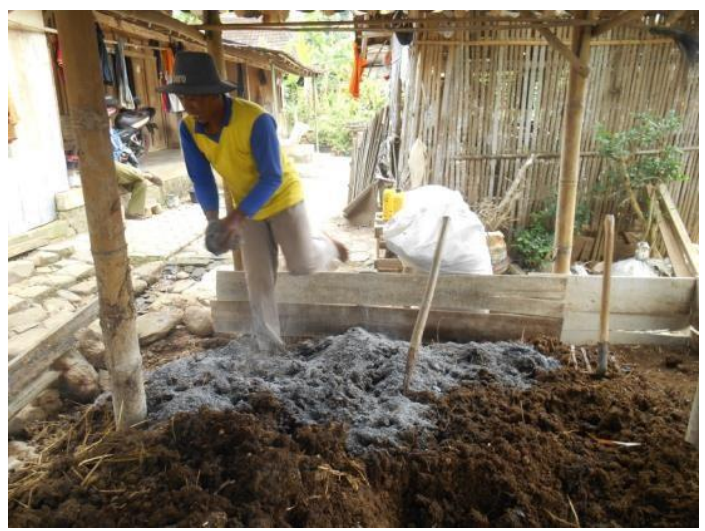

Gambar 4. Penambahan Abu Sekam Padi

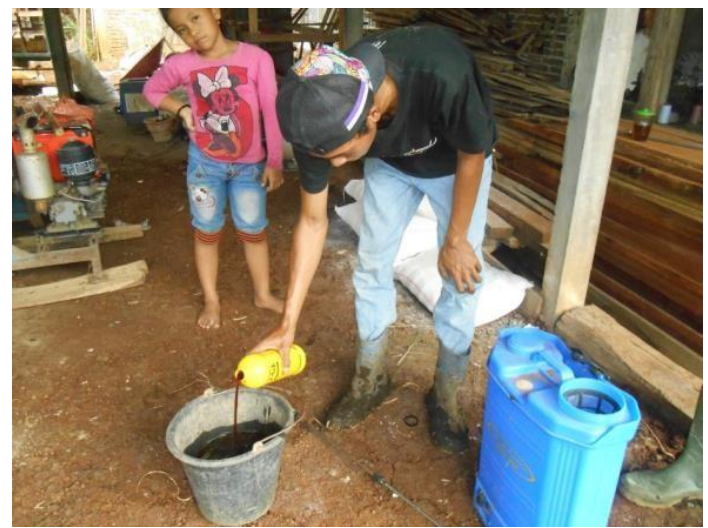

Gambar 5. Pencampuran dan aplikasi biostarter

Kegiatan pengelolaan pupuk kandang sapi di Desa Jetis, Kecamatan Sambirejo, Kabupaten Sragen dengan memanfaatkan bakteri dekomposer untuk meningkatkan mutu pupuk organik di kelompok tani dalam rangka Tri Darma Perguruan Tinggi telah dilaksanakan sampai tutorial kepada mitra tentang 
pengelolaan pupuk organik. Hasil yang diharapkan pada akhir kegiatan dapat mengatasi permasalahan mitra tentang pengelolaan pupuk kandang sapi sehingga akan mendukung Desa Jetis, Kecamatan Sambirejo sebagai salah satu sentra padi organik di Kabupaten Sragen.

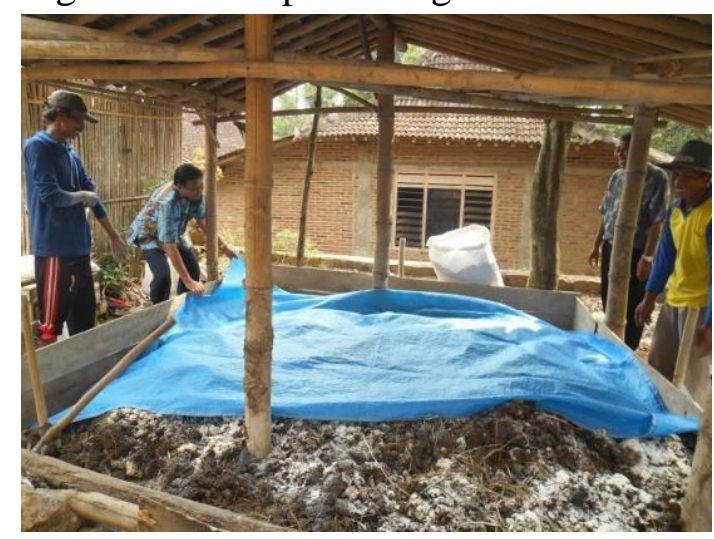

Gambar 6. Pupuk Kandang yang telah ditambah bahan pengaya ditutup menggunakan terpal.

Teknolgi pembuatan Pupuk organik dengan memanfaatkan kotoran sapi yang dikomposkan dengan menggunakan starbio/bakteri dekomposer yang dapat membuat unsur-unsur hara lebih tersedia bagi tanaman dan dapat digunakan sebagai pupuk organik di Desa Jetis Kecamatan Sambirejo, Kabupaten Sragen.

\section{KESIMPULAN}

Kegiatan pengelolaan pupuk kandang sapi di Desa Jetis, Kecamatan Sambirejo, Kabupaten Sragen dengan memanfaatkan Bifertilizer Bio2 hasil riset Perguruan Tinggi untuk meningkatkan mutu pupuk organik di kelompok tani dalam rangka Tri Darma Perguruan Tinggi telah dilaksanakan sampai tutorial kepada mitra tentang pengelolaan pupuk organik.

Hasil yang diharapkan pada akhir kegiatan dapat mengatasi permasalahan mitra tentang pengelolaan pupuk kandang sapi sehingga akan mendukung Desa Jetis, Kecamatan Sambirejo sebagai salah satu sentra padi organik di Kabupaten Sragen.

\section{DAFTAR PUSTAKA}

Murbandono, 2000. Manfaat Bahan Organik bagi tanaman. Puslit Biologi, LIPI, Bogor

Setiawan Ade Iwan. 1998. Memanfaatkan kotoran ternak. Penebar Swadaya Jakarta.

Rahardi, F., Satyawibawa, I., Setyowati R.N. 1993. Agribisnis Peternakan, Penebar Swadaya Jakarta.

Zulkarnain. 2009. Dasar-dasar Holtikultura.

Penerbit PT. Bumi Aksara, Jakarta.

Hidayat, P. dan Darwin P. 2008. pengaruh dosis kompos pupuk kandang sapi terhadap pertumbuhan dan produksi buah tomat,(Skripsi S-1 jurusan budidaya pertanian fakultas pertanian Universitas Lampung).

Afandhie R dan N.W Yuwono. 2002. Ilmu Kesuburan Tanah. Penerbit Kanisius, Yogyakarta. Anonim, 2007 